\title{
Discussion Paper No. 10-038 \\ Modeling and Explaining the Dynamics of European Union Allowance Prices at High-Frequency
}

Christian Conrad, Daniel Rittler, and Waldemar Rotfuß

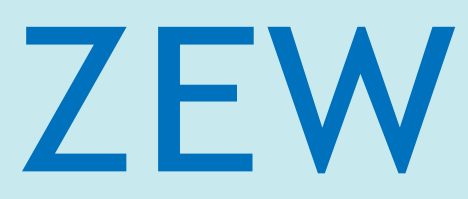

Zentrum für Europäische Wirtschaftsforschung $\mathrm{GmbH}$ Centre for European Economic Research 


\title{
Discussion Paper No. 10-038 \\ Modeling and Explaining the Dynamics of European Union Allowance Prices at High-Frequency
}

\author{
Christian Conrad, Daniel Rittler, \\ and Waldemar Rotfuß
}

Download this ZEW Discussion Paper from our ftp server:

ftp://ftp.zew.de/pub/zew-docs/dp/dp10038.pdf

Die Discussion Papers dienen einer möglichst schnellen Verbreitung von neueren Forschungsarbeiten des ZEW. Die Beiträge liegen in alleiniger Verantwortung der Autoren und stellen nicht notwendigerweise die Meinung des ZEW dar. 


\section{Non-Technical Summary}

This paper contributes to a relatively new research area called "carbon finance". In simple terms, carbon finance deals with finance and carbon dioxide permit market related issues. The research focuses, for example, on the stochastic properties of carbon permit prices or their empirical relation to fundamental price drivers. The existing literature deals primarily with EU carbon permits - the so called European Union Allowances (EUAs). Recent results suggest that EUA prices are closely connected to energy prices, in particular to electricity, gas and crude oil prices. In addition, sectoral production or regulatory issues also significantly determine the EUA price. Other results show that macroeconomic risk factors, such as the default spread, the short-term interest rates or selected market portfolios are only loosely related to the EUA price.

This paper extends the existing literature on carbon finance by modeling the adjustment process of EUAs prices to scheduled macroeconomic and regulatory announcements. The modeling focuses on high-frequency price dynamics and takes into account the most distinctive features of EUA returns, in particular intraday periodicity, volatility clustering and volatility persistence. The analysis shows that the high-frequency EUA price dynamics are very well captured by a fractionally integrated asymmetric power GARCH process - a process based on fractional integration that is able to capture the slow decay in the autocorrelation function of the squared returns. The decisions of the European Commission on second National Allocation Plans (that are used as a proxy for scheduled regulatory announcements) have a strong and immediate impact on EUA prices. On the other hand, the results suggest that scheduled macroeconomic announcements are only weakly connected to the EUA price. According to these results, the information processing in the EU carbon permit market at high-frequency seems to differ from the price formation in foreign exchange, bond or equity markets, where prices react strongly and immediately to scheduled macroeconomic releases. 


\section{Zusammenfassung (Non-Technical Summary in German)}

Dieses Papier leistet einen Beitrag zu einem neuen Forschungsgebiet, welches sich unter dem Begriff "Carbon Finance" zusammenfassen lässt. Carbon Finance befasst sich mit CO2-Zertifikaten aus finanzwirtschaftlicher Perspektive. Die Forschung konzentriert sich bspw. auf die stochastischen Eigenschaften von CO2-Emissionsberechtigungen oder ihre empirische Beziehung zu fundamentalen Einflussfaktoren. Die aktuelle Literatur setzt sich vorwiegend mit europäischen Emissionsberechtigungen auseinander, den so genannten European Union Allowances (EUAs). Neue Ergebnisse zeigen, dass die EUA Preise sehr stark von Energiepreisen beeinflusst werden, insbesondere von Strom-, Gas- und Erdölpreisen. Darüber hinaus haben branchenspezifische Industrieproduktion sowie regulierende Maßnahmen einen signifikanten Einfluss auf die EUA Preise. Andererseits zeigen die Ergebnisse, dass zwischen EUA Preisen und makroökonomischen Risikofaktoren, wie bspw. der Ausfallrisikoprämie, kurzfristigen Zinssätzen oder ausgewählten Markt-Portfolios, nur eine schwache Beziehung besteht.

Diese Arbeit ergänzt die bestehende Carbon Finance Literatur durch die Modellierung von EUA Preisände-rungen, die in Folge von planmäßigen makroökonomischen und regulatorischen Ankündigungen erfolgen. Die Modellierung konzentriert sich auf hochfrequente Preisänderungen unter Berücksichtigung ihrer wichtigsten Eigenschaften, wie bspw. Intratagesvolatilität, Volatilitätsclustern oder der starken Persistenz der Volatilität. Die Ergebnisse zeigen, dass die hochfrequente EUA Preisdynamik sehr gut mit Hilfe eines fraktional integrierten asymetrischen Power-GARCH Prozesses erfasst werden kann ein auf fraktionaler Integration basierender Prozess, der es ermöglicht die starke serielle Autokorrelation der quadrierten Preisänderungen abzubilden. Die Entscheidungen der Europäischen Kommission über die Höhe der zweiten Nationalen Allokationspläne (die als Proxy für planmäßige regulatorische Ankündigungen verwendet werden) haben einen starken und unmittelbaren Einfluss auf die EUA Preise. Im Gegensatz dazu legen die Ergebnisse nahe, dass planmäßige makroökonomische Ankündigungen nur einen schwachen Einfluss auf die EUA Preisänderungen ausüben. Auf Basis dieser Ergebnisse scheint sich die Informationsverarbeitung auf dem Markt für europäische Emissionsberechtigungen von derjenigen auf Aktien-, Anleihe- oder Devisenmärkten, in denen Preise schnell und unmittelbar auf planmäßige makroökonomischen Ankündigungen reagieren, zu unterscheiden. 


\title{
Modeling and Explaining the Dynamics of European Union Allowance Prices at High-Frequency*
}

\author{
Christian Conrad†, Daniel Rittler \\ $\dagger \ddagger$ University of Heidelberg, Heidelberg, Germany

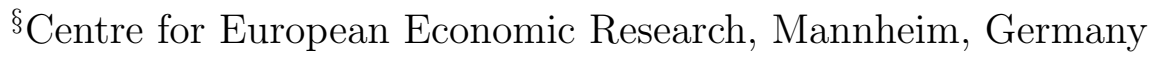

June 8, 2010

\begin{abstract}
In this paper we model the adjustment process of European Union Allowance (EUA) prices to the releases of announcements at high-frequency controlling for intraday periodicity, volatility clustering and volatility persistence. We find that the high-frequency EUA price dynamics are very well captured by a fractionally integrated asymmetric power GARCH process. The decisions of the European Commission on second National Allocation Plans have a strong and immediate impact on EUA prices. On the other hand, our results suggest that EUA prices are only weakly connected to indicators about the future economic development as well as the current economic activity.
\end{abstract}

Keywords: EU ETS, EUA, Announcement Effects, Price Formation, Long Memory

JEL Classification: C22, G13, G14, Q50

*We thank Jürgen Kähler, Uta Pigorsch, Reint Gropp and the participants of the annual meeting of the Verein für Socialpolitik (Magdeburg, 2009) for comments and suggestions on earlier versions of this paper. We are grateful to Henry Bakker and Lothar Heßler for the data provision. Andreas Beck provided valuable research assistance. Support from the Förderkreis Wissenschaft und Praxis am Zentrum für Europäische Wirtschaftsforschung is also gratefully acknowledged. The usual disclaimer applies.

${ }^{\dagger}$ Corresponding author: Christian Conrad, Department of Economics, University of Heidelberg, Bergheimer Strasse 58, 69115 Heidelberg, Germany, E-Mail: christian.conrad@awi.uni-heidelberg.de; Phone: $+49 / 6221 / 54 / 3173$.

${ }^{\ddagger}$ Daniel Rittler, Department of Economics, University of Heidelberg, Bergheimer Strasse 20, 69115 Heidelberg, Germany, E-Mail: daniel.rittler@awi.uni-heidelberg.de; Phone: +49/6221/54/2926.

${ }^{\S}$ Waldemar Rotfuß, Centre for European Economic Research (ZEW), Mannheim, P.O. Box 1034 43, 68034 Mannheim, Germany, E-mail: rotfuss@zew.de; Phone: +49/621/1235/141, fax: $+49 / 621 / 1235 / 223$. 


\section{Introduction}

In this article we analyze the high-frequency price dynamics of European Union Allowances (EUAs) traded on the European Union Emissions Trading Scheme (EU ETS). Our contribution to the literature on the modeling of EUA prices is twofold.

First, we establish that EUA high-frequency return data are characterized by a distinguished intraday seasonality pattern in their second conditional moment. Such intraday seasonality has been proven to exist in other financial markets such as stock returns and exchange rates (see Andersen and Bollerslev (1997) and Andersen and Bollerslev (1998)), but the finding of such a pattern which is linked to the intensity of the intraday market activity is novel for EUA returns. Hence, a meaningful econometric analysis of the data requires in a first step to filter the returns in order to remove the seasonality. The autocorrelation function of the absolute values of the appropriately filtered return series is then shown to display a very slow decay behavior which is typical for time series obeying long memory in their conditional second moment. In addition, there is clear evidence for heteroskedasticity and asymmetric responses to positive and negative shocks in the conditional variance. We find that a fractionally integrated asymmetric power GARCH (FIAPGARCH) model is best suited for capturing all the stylized facts in the high-frequency EUA returns. This model has been suggested by Tse (1998) and combines the long memory property of the fractionally integrated GARCH (FIGARCH) specification of Baillie, Bollerslev, and Mikkelsen (1996) with the asymmetric power GARCH (APGARCH) model of Ding, Engle, and Granger (1993). While previous research on EUA prices had already established the conditional heteroskedasticity in daily returns (e.g. Benz and Trueck (2009), Paolella and Taschini (2008) and Chevallier (2009)), the finding of long memory in intraday returns is novel to this article. Since the FIAPGARCH model nests several other GARCH specifications under certain parameter constraints, we can use standard information criteria and likelihood ratio tests in order to rank the competing models. We clearly show that the long memory FIAPGARCH specification outperforms the short memory GARCH models in terms of modeling performance.

Second, we provide a detailed analysis of the real-time response of EUA prices to the releases of major macroeconomic announcements. The previous literature has identified political and institutional decisions on the overall cap intensity, economic activity, energy prices and temperature as the main EUA price drivers. For a comprehensive survey on current research we refer to the overview article by Zhang and Wei (2010). Our contribution has many distinguishing features. First of all, the previous literature was entirely based on the analysis of daily data. However, since the response to news usually 
occurs very quickly in financial markets, our high-frequency perspective appears to be more appropriate. Further, for measuring the strength of the response of EUA prices to the release of new information, we construct surprise variables which are based on the difference of the actual figures and the market's expectations. The expectations data are obtained from surveys among market participants. This approach to measure announcement effects is commonly used in e.g. exchange rate markets (see Andersen, Bollerslev, Diebold, and Vega (2003) and Conrad and Lamla (2010)). In contrast, previous articles on the link between EUA prices and economic fundamentals have either exclusively made use of the actual figures, but did not take into account expectations, or simply employed dummy variables which indicated the occurrence of certain news events, but did not control for the specific content of the news. In the empirical analysis we focus on the releases of $i$ ) the European Commission's (EC's) decisions on second National Allocation Plans (NAPs), ii) macroeconomic indicators about the future economic outlook and iii) figures about the current economic stance. We show that the EUA prices react most strongly to the EC's decisions on second NAPs. The response occurs immediately after the release of the new information and induces significant price adjustments for at least 60 minutes. The direction of the price adjustment is in line with what economic theory would suggest: a higher than expected allocation of emission rights leads to a fall in the EUA price. This finding extends and complements the results in Mansanet-Bataller and Pardo (2009) and Rotfuß, Conrad, and Rittler (2009). The reaction of the EUA prices to the releases of macroeconomic figures is less strong. Nevertheless, whenever we find significant reactions, they are generally of the expected sign. The econometric analysis reveals that EUA prices weakly react to news about the future economic development. Positive news which indicate higher economic activity lead to the expectation of increasing demand for emission allowances and, hence, an increase in the EUA price. This finding is of central importance, because in a previous study Chevallier (2009) had argued that "the carbon market is only remotely connected to macroeconomic variables". Hence, our results based on a high-frequency framework provide supporting evidence for his conclusion which was based on the analysis of daily data. Finally, we establish that EUA prices also respond to news about the current economic stance (i.e. production activity). Our findings are in line with the theoretical argument put forward by Alberola, Chevallier, and Chèze (2009a) and Alberola, Chevallier, and Chèze (2009b), namely that the reaction will depend on the potential short/long compliance positions of the industrial sectors which participate in the trading scheme. Our estimates suggest that on average industrial sectors are characterized by having long compliance positions.

The remainder of this article is organized as follows. Section 2 discusses the main features 
of the EU ETS. Related literature is reviewed in Section 3. Section 4 describes the data and the econometric models. Section 5 presents the empirical results, while Section 6 concludes.

\section{The European Union Emissions Trading Scheme}

In 2003, the European Union (EU) established a scheme for greenhouse gas emission allowance trading. The scheme is substantially larger and by far more complex than the pioneering U.S. system for sulfur dioxide. It is based on the Directive 2003/87/EC and formally entered into operation in January 2005; ten years after the US predecessor began operating. The purpose of the European trading scheme is to promote reductions of greenhouse gas emissions in a cost-effective and economically efficient manner. It aims to assist EU Member States (member states in the following) in meeting their commitments under the Kyoto Protocol at minimum costs and has been called the "New Grand Policy Experiment" of market-based policies in environmental regulation (see Kruger and Pizer (2004), for more details). The scheme requires selected industrial units to participate in the trading of emission allowances. The program covers emissions from four broad sectors: energy, production and processing of ferrous metals, minerals, and other energy-intensive activities (in particular production of pulp and paper). The aviation sector is going to be included in the EU ETS from 2012 onwards. Besides carbon dioxide (CO2) - that accounts for the biggest share of covered gases - five other gases (methane $(\mathrm{CH} 4)$, nitrous oxide (N2O), hydrofluorocarbons (HFCs), perfluorocarbons (PFCs), sulphur hexafluoride $(\mathrm{SF} 6))$ that are supposed to have an impact on climate change are covered by the scheme. One emission allowance grants the participating installation (or some other holder of it) the right to emit one metric tonne of carbon dioxide equivalent (tCO2e) during a specified commitment phase. For a legal description of the EU ETS, see European-Parliament and Council (2003).

The EU ETS is divided into three commitment phases (Phase I: 2005-2007, Phase II 2008-2012, Phase III: 2013-2020) and runs on the basis of a "cap-and-trade" system. The EU ETS emission cap is defined for each commitment phase by the so called "National Allocation Plans". We term these various plans as first, second, or third NAPs according to the commitment phases. The NAPs are defined by each member state and contain both the national total of allowances as well as a rule for distributing the allowances to the participating installations. The EC approves each NAP and thereby sets the EU ETS emission cap. In total there are 27 NAPs and 27 decisions of the EC on the 
first and second NAPs, respectively. ${ }^{1}$ The allowances are grandfathered or auctioned, whereas grandfathering has been the most common allocation rule in the first two phases. According to European-Parliament and Council (2009) auctioning should be the basic principle for allocation from 2013 onwards. The allowances are freely tradable after they have been allocated to the participating installations.

The participating installations are required to verify their emissions and to surrender the equivalent number of EUAs or other eligible instruments to a competent authority on an annual basis. Installations that have spare allowances can sell them on the market. Inversely, any installation that lacks allowances has to purchase them from other installations or market participants. All emissions that are not covered by surrendered EUAs or other eligible instruments are fined with $40 € /$ tCO2e (in Phase I) or $100 € /$ tCO2e (in Phase II) and additionally have to be turned in at the next compliance date.

The EU ETS is the largest emissions market in the world, but it is relatively small compared to, e.g., energy markets. The annual emission cap equals 2299 million tCO2e in the first commitment period and 2083 million tCO2e in the second. The cap (as an approximation of outstanding EUAs) and the average annual EUA price suggest an annual market value of $€ 30$ billion in the first phase and of $€ 47$ billion in the second phase, respectively. According to Farrimond (2008), the European electricity market has an estimated annual market value of approximately $€ 224$ billion.

Trading in emission rights takes place on organized markets and over-the-counter (OTC). The trading in EUAs is not specifically regulated or supervised by the EC, although it sets the framework. Trading is regulated by the member states and their national regulating authorities. The most liquid EUA spot market is BlueNext in Paris, which attracts approximately 70 percent of the total daily turnover of the whole organized spot market. Besides an active EUA spot market there is also a vital derivatives market, where futures, options, and other derivatives on EUAs are traded. The most liquid futures market is ICE Futures in London, which absorbs circa 90 percent of the daily turnover in EUA futures. The trading rules on all organized EUA spot and futures markets are largely identical.

\footnotetext{
${ }^{1}$ Note that the national totals in Phase III will decrease linearly from the average national quantity of allowances in Phase II without any additional EC's approvals. For more details, see European-Parliament and Council (2009).
} 


\section{Related Literature}

This article can be considered as being part of a relatively new research area called "carbon finance". The recent papers by Paolella and Taschini (2008), Benz and Trueck (2009) and Daskalakis, Psychoyios, and Markellos (2009) primarily focus on the stochastic properties of EUA prices at a daily frequency. Among other things, these authors provide evidence for conditional heteroskedasticity in daily EUA returns. In another stream of articles the authors try to establish which fundamentals are the main price drivers in the EUA market. The role of regulatory issues has been considered by Mansanet-Bataller and Pardo (2009) and Alberola, Chevallier, and Chèze (2008) who find that the approval of the overall cap or the verification of actual emissions significantly affect the EUA price. Other fundamental factors such as energy prices, weather or the overall economic activity are analyzed, among others, in Mansanet-Bataller, Pardo, and Valor (2007) and Alberola, Chevallier, and Chèze (2009a). Their results suggest that EUA prices are closely connected to energy markets, in particular to electricity, gas and crude oil prices. In addition, Alberola, Chevallier, and Chèze (2009b) conclude that sectoral production also significantly determines the EUA price. To the contrary, it has been argued by Chevallier (2009) that macroeconomic risk factors, such as the default spread, the short-term interest rates or selected market portfolios are only loosely related to the EUA price.

Despite the growing interest in "carbon finance", very few studies focus at the relation between the EUA price and its fundamentals at high-frequency. The first work in this direction has been done by Benz and Hengelbrock (2008) and Rotfuß (2009), where the former analyze the joint development of two different exchange-based EUA price series, and the latter provides selected features of the intraday price formation and volatility in the EU ETS. More recent studies, for example Rittler (2009), focus on the relation between EUA spot and futures prices at high-frequency. The present article builds on the study of Rotfuß, Conrad, and Rittler (2009) in which the relation between EUA prices and one fundamental factor, namely the determination of the overall supply of EUAs in the second phase is analyzed. 


\section{Data and Methodology}

\subsection{Data}

\subsubsection{Price Data}

In the empirical analysis we employ high-frequency price data for second phase EUAs which were obtained from the ICE Futures/European Carbon Exchange (ECX), the leading exchange for trading in EUA futures. We focus on price series of the EUA futures contracts maturing in December 2008 (from 01/11/2006 to 15/12/2008) and in December 2009 (from 16/12/2009 to 18/03/2009). Data prior to November 2006 is not considered due to low liquidity in these instruments. Both EUA futures contracts have a maturity of more than three years. They were launched in 2005 and matured on 12/15/2008 and $12 / 14 / 2009$, respectively. In total, we consider 601 trading days, whereby we restrict the analysis to on-exchange transactions. Trading in ICE Futures takes place every working day between 7:00 and 17:00 GMT. The raw data files contain a total of 405,939 irregularly spaced transaction records. Each transaction record consists of the transaction price and the corresponding time stamp (measured up to the second) in GMT. A more detailed description of the data can be found in Rotfuß (2009).

In order to explore the intraday price dynamics, we transform the irregularly spaced transaction prices to equidistant price series. Figure 1 displays the equidistant 10-minutes EUA prices for the period under consideration. The frequency of the series used in our analysis is chosen to be $h=10,30$ and 60 minutes, whereas 7:00 GMT is the first equidistant point in time. At each equidistant point in time the corresponding price is calculated as the mean of the preceding and the immediately following price, unless there is a transaction at the equidistant point itself. If there is no transaction at 17:00 GMT, the last equidistant price equals the last recorded transaction price. To avoid overnight effects, we do not take the mean of transaction prices of two different days.

$$
\text { Figure } 1 \text { about here. }
$$

Equidistant returns are constructed from the price series as follows

$$
R_{t, k}(h)=100 \times\left(\log \left(P_{t, k}(h)\right)-\log \left(P_{t, k-1}(h)\right)\right), \quad t=1, \ldots, T \quad \text { and } \quad k=1, \ldots, K(h),
$$

where $P_{t, k}(h)$ represents the equidistant EUA price at the end of the $k$-th interval at day $t$, given the considered frequency $h . T$ is the total number of trading days and $K(h)$ the 
number of equidistant intervals per trading day. $P_{t, 0}(h)$ is defined as the last equidistant price on the preceding trading day $t-1$, unless there is a transaction exactly at 7:00 GMT.

At all three frequencies, the descriptive statistics (not reported) reveal that the EUA returns have a mean which is not significantly different from zero, are slightly skewed to the right and have a kurtosis that is significantly greater than three. The Jarque-Bera statistics reject normality and the outcome of the Engle LM tests suggest that there is conditional heteroskedasticity. As often reported for high-frequency data, there is some evidence for serial correlation at low lags in the high-frequency returns, possibly due to microstructure effects. In sharp contrast, Figure 2 shows that the absolute returns are highly correlated even for long lags.

\section{Figure 2 about here.}

The figure depicts exemplarily the sample autocorrelation function of the 10-minutes absolute EUA returns for five consecutive trading days. The intraday periodic pattern is clearly observable. Due to the 10-minutes frequency and a trading session of ten hours, we have 60 equidistant intervals per trading day. The figure reveals a peak at the first lag and a fast decay of the sample autocorrelation function within the first half of the trading day (up to lag 30). After lag 30, the autocorrelation begins to increase towards a second peak at the beginning of the next trading day (lag 60). The same seasonality pattern is observed for the following days, whereas the amplitude of the subsequent peaks is slowly decreasing. The pattern results from the intraday seasonality due to the time-varying intensity of market activity which is illustrated in Figure 3.

\section{Figure 3 about here.}

The figure shows the average absolute returns, $f_{k}(h)=\frac{1}{T} \sum_{t=1}^{T}\left|R_{t, k}(h)\right|$, for each interval $k=1, \ldots, 60$. The average absolute returns are high at the beginning of the trading session and then decrease until mid-day. After mid-day, the average absolute returns are again slightly increasing. Although less pronounced, this pattern of the absolute EUA returns resembles the typical intraday U-shaped pattern observed in other financial markets (see, e.g., Andersen and Bollerslev (1997)).

There are several ways to deal with the intraday seasonality (see, e.g., Martens, Chang, and Taylor (2002)). A simple but very effective method is to standardize $R_{t, k}$ according to the following rule: 


$$
r_{t, k}(h)=\frac{R_{t, k}(h)}{f_{k}(h)}
$$

The standardization simply scales each return $R_{t, k}$ by the average absolute return of the interval $k$. Figure 4 illustrates the effect of the filtering by displaying the sample autocorrelation function of $\left|r_{t, k}\right|$ for five consecutive trading days, where again we fix the frequency at $h=10$. As evident from the figure, the sample autocorrelation function does not exhibit any remaining seasonality. In fact, it decreases smoothly with increasing lags. However, its slow decay points to a long memory property in the volatility of EUA returns (see Andersen and Bollerslev (1997)). Having observed this property, it appears reasonable to use a long memory GARCH specification to asses the impact of the announcement releases on the EUA prices.

\section{Figure 4 about here.}

\subsubsection{Announcement Data}

As mentioned before, previous research has identified political and institutional decisions on the overall cap stringency, energy prices, temperature events and economic activity as the main EUA price drivers. In our high-frequency analysis of announcement effects we will focus on regulatory issues and measures of economic activity. Further, among the measures of economic activity we distinguish between those which capture the future economic outlook and those which capture the contemporaneous macroeconomic situation. More specifically, we consider the releases of $i$ ) the EC's decisions on second NAPs that represent a proxy for scheduled regulatory announcements, ii) leading economic indicators that are supposed to reflect the views of the market participants on the future economic development, and iii) macroeconomic figures that are supposed to capture the real economic activity in the European Union and its biggest members states (Germany, Great Britain, and France). In addition, we also make use of data from those US announcements which have been shown to affect other European assets prices in previous studies (see, e.g., Andersson, Overby, and Sebestyen (2009)). The econometric analysis of the announcement effects is then based on the differences of realized and expected figures.

\section{Table 1 about here.}

In total we make use of $i=13$ announcement series which span the period $11 / 2006$ to $03 / 2009$. The individual observations for each of the announcement series consist of the 
time stamp of the announcement release $(t, k)$, the realized value $y_{t, k}^{i}$, and the median $\widehat{y}_{t, k}^{i}$ of the corresponding expectations of the market participants. With the exception of the decisions on second NAPs, all realized and expected data were obtained from the Forex Factory (forexfactory.com, FF in the following) database. FF compiles the expectations either from the Bloomberg or from the Reuters press releases, which are publicly available shortly after the announcements. The expectation data are consensus forecasts, which Bloomberg and Reuters obtain by means of surveys few days prior to the announcements. The data on the EC's decisions on second NAPs were obtained from Rotfuß, Conrad, and Rittler (2009). In contrast to the FF data, they are constructed from a model of expectation formation, where agents anticipate the decisions of the EC on second NAPs. The model assumes that market participants expect the national total in Phase II to be the minimum of either the number of EUAs submitted by the member state or a lump sum cut amount of its national total in Phase I. For a more detailed discussion of the model see Rotfuß, Conrad, and Rittler (2009).

An overview of the announcement data along with a test for the unbiasedness of the expectations is provided by Table 1. The standard procedure to test for the unbiasedness of expectations is to run a linear regression of the realized value on an intercept and the expected value. The expectations can be assumed to be unbiased, if the estimates for the intercept and the slope coefficient are not statistically different from zero and unity, respectively. As can be seen from Table 1 , in all regressions the $R^{2}$ is relatively high and the null hypothesis of unbiased expectations, $H_{0}: \beta_{1}=0$ and $\beta_{2}=1$, can only be rejected in two (four) out of the thirteen cases at the 5\% (10\%) level. Thus, we conclude that the survey expectations can be considered as being of good quality.

Since the units of measurement differ across the various announcement variables, we follow Andersen, Bollerslev, Diebold, and Vega (2003) and standardize the surprise variables, i.e. the difference between the realized and expected values, as:

$$
S_{t, k}^{i}=\frac{y_{t, k}^{i}-\widehat{y}_{t, k}^{i}}{s^{i}}
$$

where $s^{i}$ is the sample standard deviation of the forecast error for announcement $i$. We refer to the resulting variables $S_{t, k}^{i}$ as the standardized surprises.

Next, we briefly discuss the expected effects of surprises in the three groups of announcement variables. Since a positive surprise in the NAP represents an unexpected increase of the national total in Phase II of a member state, we should expect a price decline simply because of increasing supply. Similarly, better than expected figures on the future economic development should signal a higher future demand for emission allowances 
because of increasing economic activity and, hence, an increase in EUA prices. The expected response to the actual economic activity is more complex. On the one hand, higher than expected actual activity should induce higher demand and therefore increasing EUA prices. On the other hand, the response to surprises in the actual activity will depend on the potential long/short compliance positions held by the industrial sectors. Note, that the expectations reported from the participants of the survey do not necessarily have to coincide with the projections of the sectors which indeed have to deliver the allowances. E.g. the results presented in Alberola, Chevallier, and Chèze (2009b) suggest that in the period 2005-2006 there has been a predominance of net long compliance positions in important industrial sectors. In such a situation even a positive surprise on the actual economic activity can lead to declining EUA prices.

\subsection{Methodology}

In order to capture the news effects on EUA prices, we model the continuously compounded EUA returns as a function of their own first lag and the contemporaneous and $P$ lagged values of the standardized surprise variables. To simplify the notation, we now change the index of the return and surprise variables from $(t, k)$ to $n$, where $n=1, \ldots, T K$. The mean equation is then given by

$$
r_{n}=\mu+\theta r_{n-1}+\sum_{i=1}^{13} \sum_{p=0}^{P} \theta_{i, p} S_{n-p}^{i}+\varepsilon_{n}
$$

where the error term $\varepsilon_{n}$ is given by $\varepsilon_{n}=\sigma_{n} Z_{n}$ with $\left\{Z_{n}\right\}$ being a sequence of independent and identically distributed random variables with $\mathbf{E}\left(Z_{n}\right)=0, \mathbf{E}\left(Z_{n}^{2}\right)=1$ and $\sigma_{n}^{2}$ being the conditional variance. Since the empirical autocorrelation function of the absolute filtered returns revealed a clear pattern of long memory and persistence, we follow Tse (1998) and model the conditional variance as a fractionally integrated asymmetric power GARCH (FIAPGARCH $(1, d, 1))$ process given by

$$
(1-\beta L) \sigma_{n}^{\delta}=\omega+\left((1-\beta L)-(1-\phi L)(1-L)^{d}\right)\left(\left|\varepsilon_{n-1}\right|-\gamma \varepsilon_{n-1}\right)^{\delta}
$$

where $L$ denotes the lag operator and $\beta / \phi$ are the autoregressive/moving average parameters of the variance equation. The fractional differencing parameter $0 \leq d \leq 1$ allows us to capture the long memory in the volatility and $\delta>0$ denotes the optimal power transformation. Finally, the asymmetry term $|\gamma|<1$ ensures that positive and negative innovations of the same size can have asymmetric effects on the conditional variance. In 
addition, for the conditional variance to be non-negative almost surely for all $n$, the parameter combination $(\beta, d, \phi)$ has to satisfy the inequality constraints derived in Conrad (2010) and Conrad and Haag (2006).

The flexible FIAPGARCH specification nests several standard GARCH models. For $\delta=2$ it reduces to an asymmetric FIGARCH (FIAGARCH) specification and under the additional constraint that $\gamma=0$ to the symmetric FIGARCH one (see Baillie, Bollerslev, and Mikkelsen (1996)).

On the other hand, for $d=0$ the model reduces to a short memory asymmetric power GARCH (APGARCH) specification and under the additional constraint that $\delta=2$ to the asymmetric GARCH (AGARCH) model (see Ding, Engle, and Granger (1993)). In this last case, the conditional variance takes the familiar form $\sigma_{n}^{2}=\omega+\alpha\left(\left|\varepsilon_{n-1}\right|-\gamma \varepsilon_{n-1}\right)^{2}+$ $\beta \sigma_{n-1}^{2}$ with $\alpha=\phi-\beta$.

All models will be estimated by using the quasi-maximum-likelihood method as implemented by Laurent and Peters (2002) in the G@RCH package for Ox, which allows us to draw robust inference even if the return data are non-Gaussian. Finally, we can use standard information criteria and likelihood ratio tests to discriminate between the most general FIAPGARCH model and the nested GARCH specifications (see Conrad, Karanasos, and Zeng (2010)).

\section{Empirical Results}

\subsection{Baseline Specifications}

We begin the empirical analysis by first estimating the four GARCH specifications at the 10-, 30- and 60-minutes frequency without including any explanatory variables. By doing so, we will identify the GARCH specification which is most suited for modeling the high-frequency EUA return data. The results are presented in Tables 2, 3 and 4 . At the 10-minutes frequency, in all four GARCH specifications the autoregressive and moving average parameters are highly significant. In addition, the asymmetry term is significantly positive in all four models, which suggests that the conditional variance of EUA returns increases considerably more in response to negative innovations than to positive ones of the same size. The fractional differencing parameter in the FIAGARCH and FIAPGARCH models take values around 0.25 which are significantly above zero. Such a degree of volatility persistence is well in line with the ones observed in other financial markets, such as exchange rates (see, e.g., Conrad and Lamla (2010)). Clearly, the evidence for 
long memory which was already evident in Figure 4 is reinforced by our coefficient estimates. $^{2}$ The estimated FIAGARCH and FIAPGARCH parameter combinations $(\beta, d, \phi)$ satisfy the inequality constraints derived in Conrad (2010) and, thus, guarantee the nonnegativity of the conditional variances. Further, the optimal power transformation in the FIAPGARCH model is estimated to be significantly greater than two and, hence, restricting it to two may lead to suboptimal modeling and forecasting performance (see Brooks, Faff, and McKenzie (2000)). Comparing the Akaike and Schwartz information criteria (AIC and SIC) of the FIAPGARCH model with those from the models which impose the restrictions $\delta=2$ (FIAGARCH), $d=0$ (APGARCH) or $\delta=2$ and $d=0$ (AGARCH) clearly leads to the conclusion that the most general FIAPGARCH specification is the preferred one. This conclusion is reinforced from the results of the likelihood ratio tests, which clearly reject the restricted models in favor of the most general specification in all cases. Also, the Ljung-Box statistics show that there is no remaining serial correlation in the squared standardized residuals from the FIAPGARCH specification. In sharp contrast, the hypothesis of uncorrelated squared standardized residuals is strongly rejected for the short memory APGARCH and AGARCH models. Finally, in the mean equation the estimated constants are insignificant for all four models, but the estimated first order autoregressive coefficient is significantly positive.

\section{Table 2 about here.}

As can be seen from Tables 3 and 4, the empirical results for the 30- and 60-minutes frequency are very similar to the one from the 10-minutes frequency. The information criteria unanimously favor the FIAPGARCH specification as the best one. With a single exception this also holds for the likelihood ratio tests. Only at the 60-minutes frequency we cannot reject the hypothesis that $\delta=2$ in the FIAPGARCH model. Further, it is interesting to note that the estimated fractional differencing parameters are increasing with decreasing sampling frequency. Similarly, the effect of the asymmetry on the conditional variance becomes stronger with decreasing sampling frequency. Finally, while the estimated power terms are greater than two at the 10- and 30-minutes frequency, the estimated values are below two at the 60-minutes frequency.

\section{Table 3 about here.}

\footnotetext{
${ }^{2}$ Also note that the sum of the $\alpha$ and $\beta$ parameters in the two short memory GARCH specifications is close to and not significantly different from one. This feature is often called the 'integrated GARCH (IGARCH)' effect and - as argued in Baillie, Bollerslev, and Mikkelsen (1996) - is due to misspecification of the conditional variance equation because of the neglected long memory property.
} 
Table 4 about here.

In summary, based on the results for the four GARCH specifications without including any explanatory variables the most general FIAPGARCH model can be clearly identified as producing the best fit to the data at all three frequencies. Hence, in the subsequent analysis of the announcement effects we will employ the FIAPGARCH model as our baseline specification.

\subsection{Measuring Announcement Effects}

In a first step we now augment the FIAPGARCH specification from above by the contemporaneous standardized surprise variables from the 13 macroeconomic announcement series. The corresponding results at the three data frequencies are presented in Table 5.

We first focus on the releases of the EC's decisions on second NAP's. The reaction to the announcements of the EC's decisions is highly significant (at the $5 \%$ level) at the 10and 60-minutes frequency and marginally significant (at the $15 \%$ level) at the 30 -minutes frequency. In line with our discussion in Section 4.1.2, a surprise allocation of more than expected NAP's leads to an immediate decline of the EUA price, which lasts at least for 60 minutes. The price drop is strongest after 10 minutes with a value of -3.0934 and then settles at -0.6214 . This finding is line with the results reported in Rotfuß, Conrad, and Rittler (2009), who employed a cross sectional regression approach.

\section{Table 5 about here.}

Among the variables which are meant to capture the tendency of the future economic development, DE new orders and US nonfarm payrolls evoke a marginally significant price reaction after 30 - and 60-minutes (at the $10 \%$ and $15 \%$ level), respectively. As expected, in both cases the reaction is positive, which is line with the argument that the prospect of stronger economic growth will increase emissions and, thereby, the demand for allowances.

Looking at the variables which reflect the current stance of the economy, we find a negative reaction to positive surprises in the DE industrial production after 60-minutes and the US ISM manufacturer index after 30-minutes (both significant at the 5\% level). The reaction to EU industrial production is negative at the 30- and 60-minutes frequency (at the $15 \%$ and $10 \%$ level, respectively). As argued by Zhang and Wei (2010) and Alberola, Chevallier, and Chèze (2009b) this finding may be explained by the fact that industrials 
hedge their allowances and, hence, there may be a predominance of net long compliance positions in the period under consideration.

Note, that the estimated values of the structural coefficients in the three conditional mean and variance equations are almost identical to the corresponding ones that we obtained for the baseline specifications without any surprise variables in the mean equation. Also, based on the Ljung-Box statistics there is no evidence for misspecification in the squared standardized residuals.

In summary, we find that the NAP approvals have an immediate, long lasting and by far the strongest effect on EUA prices. For the other surprise variables it takes at least 30 minutes to generate a significant market reaction. Two of the variables which reflect the expectations about the future economic development have a significant effect which is of the anticipated sign. On the other hand, positive surprises on contemporaneous economic activity variables lead to a decline in EUA prices. Nevertheless, the majority of the macroeconomic releases does not appear to generate a significant reaction of the EUA prices. However, one should keep in mind that these are preliminary results, which do not take into account the complicated lead lag structure in the response to the release of macroeconomic announcements often observed in other financial markets shortly after the release. Hence, in a second step we rerun the regression at the 10-minutes frequency, but now include several lagged values of the surprise variables.

The results for this extended model are presented in Table 6. We include up to 3 lags of the standardized surprise variables such that a 40 -minutes period is covered. ${ }^{3}$

\section{Table 6 about here.}

As before, the overall reaction to the NAP announcement is negative. However, it is interesting to note that after the strong price decline within the first 10-minutes, there is a significant price reversal which is then followed a final price decline. This detailed analysis of the price reaction was not possible by simply looking at the reaction at different frequencies (as was done in Table 5), but required the inclusion of lagged surprises.

The results for the forward looking indicators confirm our previous findings. In addition to DE new orders and US nonfarm payrolls, we now find a positive and significant reaction to specific lags of the DE Ifo index and the DE ZEW index as well. Thus, better than expected economic prospects lead to increasing demand for allowances which induces the EUA price to increase.

\footnotetext{
${ }^{3}$ Including additional lagged values did not change our conclusion in a significant way. Of course, the results are available from the authors upon request.
} 
For the EU industrial production, the GB industrial production and the US ISM manufacturer index the evidence is now mixed. At some lags the estimated reaction is significantly positive, at others significantly negative. However, in two of the three cases the sum of the significantly estimated coefficients is negative, thus leading to the same conclusion as before.

Definitely, the analysis with lagged standardized surprise variables allows us to gain some additional insights into the way the EUA prices adjust to new information. The reactions that we estimated for the different models lead to a very coherent and compelling picture. Apart from the immediate reaction to EU NAPs, the response of the EUA price to the release of new information seems to take at least 10-minutes and appears to be rather tenuous. This is a remarkable finding, since in other financial markets the adjustments to news typically take place within a few minutes or even seconds (see Andersen, Bollerslev, Diebold, and Vega (2003)). The comparatively slow reaction of the EUA prices may be due to the fact that the European carbon market is still relatively new.

\section{Conclusions}

This article contributes to the steadily expanding literature on the modeling and explaining of the movements in EUA prices. The distinguishing feature of our contribution lies in investigating the price dynamics from a high-frequency perspective. Analyzing return data for the EUA futures contracts maturing in December 2008 and in December 2009, we show that the best fit is achieved by a fractionally integrated asymmetric power GARCH specification. Thus, we establish that high-frequency EUA returns do not only obey conditional heteroskedasticity, but are also characterized by long memory, power effects and asymmetry in their second conditional moments. As shown in Conrad, Karanasos, and Zeng (2010) for stock index returns, the adequate modeling of such properties is crucial for the model performance.

Moreover, we investigate how EUA prices respond to the release of the EC's decisions on second NAPs, macroeconomic announcements on the future economic development and the actual economic activity. We find that the reaction to the EC's decisions on second NAPs is immediate and of the expected sign. To the contrary, the link between EUA prices and the releases of macroeconomic figures is found to be tenuous. The empirical evidence suggests that leading economic indicators which point towards higher than expected growth in the future, induce an increase in EUA prices, whereas the response does not follow immediately but takes at least 10-minutes to occur. Also, the reaction to 
announcements on the actual economic activity is ambiguous, i.e. the sign of the response changes with the time-lag under consideration. However, the empirical results are well in line with the view that on average industrial sectors were holding long positions in emission allowances in the period under consideration. From the size and the strength of the response of EUA prices to the various data releases, we conclude that NAP announcements which directly affect the supply of emission allowances are by far the most important driving force of EUA prices. 


\section{References}

Alberola, E., J. Chevallier, and B. Chèze (2008): "Price Drivers and Structural Breaks in European Carbon Prices 2005 - 2007," Energy Policy, 36, 787-797.

(2009a): "The EU Emissions Trading Scheme: The Effects of Industrial Production and CO2 Emissions on European Carbon Prices," International Economics, 116, 95-128.

(2009b): "Emissions Compliances and Carbon Prices under the EU ETS: A Country Specific Analysis of Industrial Sectors," Journal of Policy Modeling, 31, 446462.

Andersen, T., and T. Bollerslev (1997): "Intraday Periodicity and Volatility Persistence in Financial Markets," Journal of Empirical Finance, 4, 115-158.

- (1998): "Deutsche Mark-Dollar Volatility: Intraday Activity Patterns, Macroeconomic Announcements, and Longer Run Dependencies," Journal of Finance, 53, 219-265.

Andersen, T., T. Bollerslev, F. Diebold, and C. Vega (2003): "Micro Effects of Macro Announcements: Real-time Price Discovery in Foreign Exchange," American Economic Review, 93, 38-62.

Andersson, M., L. J. Overby, and S. Sebestyen (2009): "Which News Moves the Euro Area Bond Market?," German Economic Review, 10, 1-31.

Baillie, R., T. Bollerslev, and H. Mikkelsen (1996): "Fractionally Integrated Generalized Autoregressive Conditional Heteroskedasticity," Journal of Econometrics, $74,3-30$.

Benz, E., And J. Hengelbrock (2008): "Price Discovery and Liquidity in the European CO2 Futures Market," Working Paper. Bonn Graduate School of Economics.

Benz, E., And S. Trueck (2009): "Modeling the Price Dynamics of CO2 Emission Allowances," Energy Economics, 31, 415.

Brooks, R., R. FAfF, and M. McKenzie (2000): "A Multi-Country Study of Power ARCH Models and National Stock Market Returns," Journal of International Money and Finance, 19, 377-397. 
Chevallier, J. (2009): "Carbon Futures and Macroeconomic Risk Factors: A View From the EU ETS," Energy Economics, 31, 614-625.

Conrad, C. (2010): "Non-negativity Conditions for the Hyperbolic GARCH Model," Journal of Econometrics, forthcoming.

Conrad, C., And B. HAAG (2006): "Inequality Constraints in the Fractionally Integrated GARCH Model," Journal of Financial Econometrics, 4, 413-449.

Conrad, C., M. Karanasos, and N. Zeng (2010): "Multivariate Fractionally Integrated APARCH Modeling of Stock Market Volatility: A Multi-Country Study," Journal of Empirical Finance, forthcoming.

Conrad, C., And M. Lamla (2010): "The High-frequency Response of the EUR-US Dollar Exchange Rate to ECB Monetary Policy Announcements," Journal of Money, Credit and Banking, forthcoming.

Daskalakis, G., D. Psychoyios, and R. Markellos (2009): "Modeling CO2 Emission Allowance Prices and Derivatives: Evidence from the European Trading Scheme," Journal of Banking and Finance, 33, 1230-1241.

Ding, Z., R. Engle, and C. Granger (1993): "A Long Memory Property of Stock Market Returns and a New Model," Journal of Empirical Finance, 1, 83-106.

European-Parliament, And Council (2003): "Directive 2003/87/EC of the European Parliament and of the Council of 13 October 2003," Official Journal of the European Union, L 275, 32-46.

(2009): "Directive 2009/29/EC of the European Parliament and of the Council of 23 April 2009," Official Journal of the European Union, L 140, 63-87.

FARRIMOND, J. (2008): "Analysis of activity in the energy markets 2008," Discussion paper, Financial Services Authority.

Kruger, J., And W. Pizer (2004): "Greenhouse Gas Trading in Europe: The New Grand Policy Experiment," Environment, 46, 8-23.

Laurent, S., And J. Peters (2002): "G@RCH 2.2: An Ox Package for Estimating and Forecasting Various ARCH Models," Journal of Economic Surveys, 16, 447-485.

Mansanet-Bataller, M., A. Pardo, and E. Valor (2007): "CO2 Prices, Energy and Weather," Energy Journal, 28, 67-86. 
Mansanet-Bataller, M., and T. Pardo (2009): "Impact of Regulatory Announcements on CO2 prices," Journal of Energy Markets, 2, 1-33.

Martens, M., Y. Chang, and S. Taylor (2002): "A Comparison of Seasonal Adjustment Mehtods when Forecasting Intraday Volatility," Journal of Financial Research, $25,283-299$.

Paolella, M., and L. Taschini (2008): "An Econometric Analysis of Emission Allowances Prices," Journal of Banking and Finance, 32, 2022-2032.

Rittler, D. (2009): "Price Discovery, Causality and Volatility Spillovers in European Union Allowances Phase II: A High-Frequency Analysis," University of Heidelberg, Department of Economics, Discussion Paper Series No. 492.

Rotfuss, W. (2009): "Intraday Price Formation and Volatility in the European Union Emissions Trading Scheme: An Introductory Analysis," ZEW Discussion Paper No. 09-018.

Rotfuss, W., C. Conrad, and D. Rittler (2009): "The European Commission and EUA Prices: A High-Frequency Analysis of the EC's Decision on Second NAPs," ZEW Discussion Paper No. 09-045, Mannheim.

TsE, Y. (1998): "The Conditional Heteroscedasticity of the Yen-Dollar Exchange Rate," Journal of Applied Econometrics, 13, 49-55.

Zhang, Y.-J., And Y.-M. Wei (2010): "An Overview of Current Research on EU ETS: Evidence from its Operating Mechanism and Economic Effect," Applied Energy, forthcoming. 


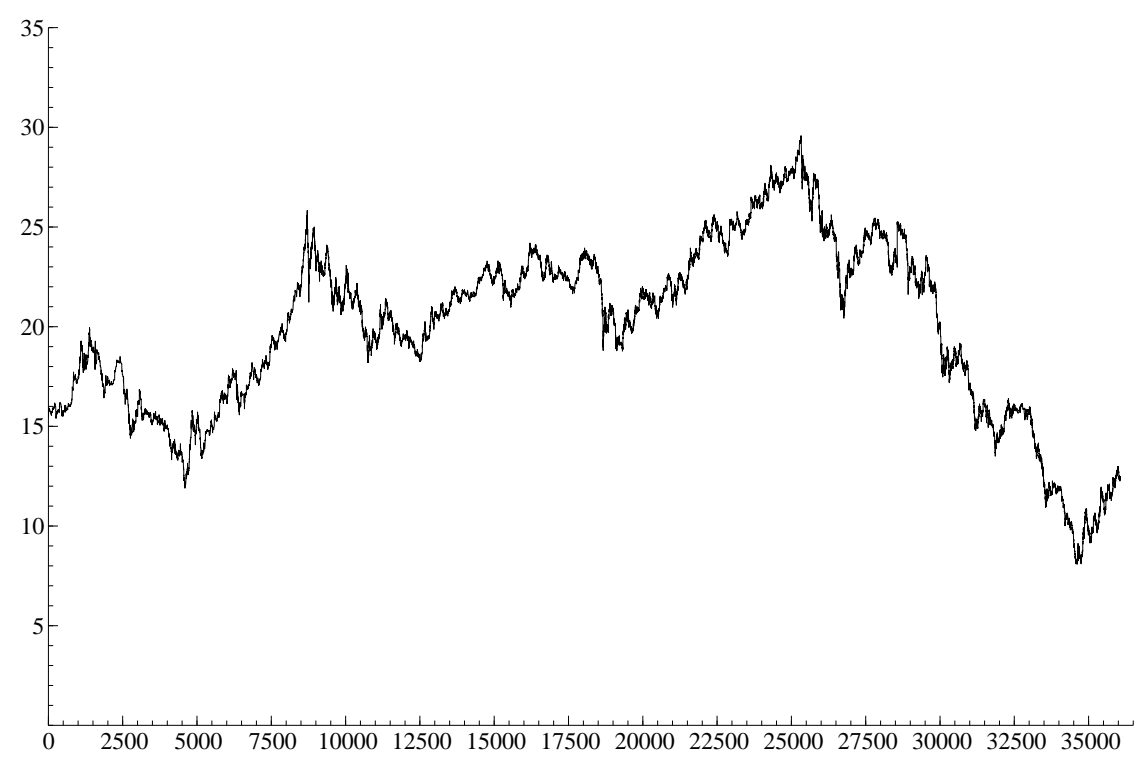

Figure 1: Equidistant 10-minutes EUA prices of the EUA futures contracts maturing in December 2008 (from 01/11/2006 to 15/12/2008) and in December 2009 (from 16/12/2009 to 18/03/2009). In total there are $K \times T=60 \times 601=36060$ observations at the 10-minutes frequency.

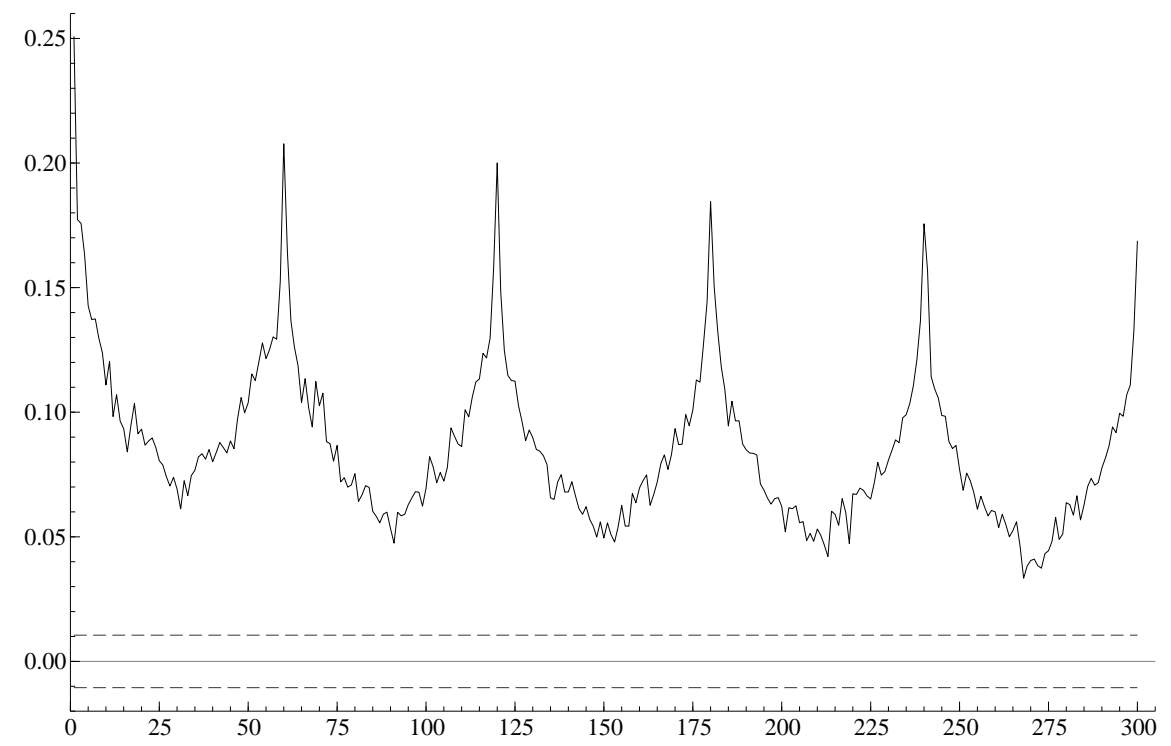

Figure 2: Autocorrelation function of absolute EUA returns $(h=10)$ for five consecutive trading days. Dashed lines represent $95 \%$ confidence bands. 


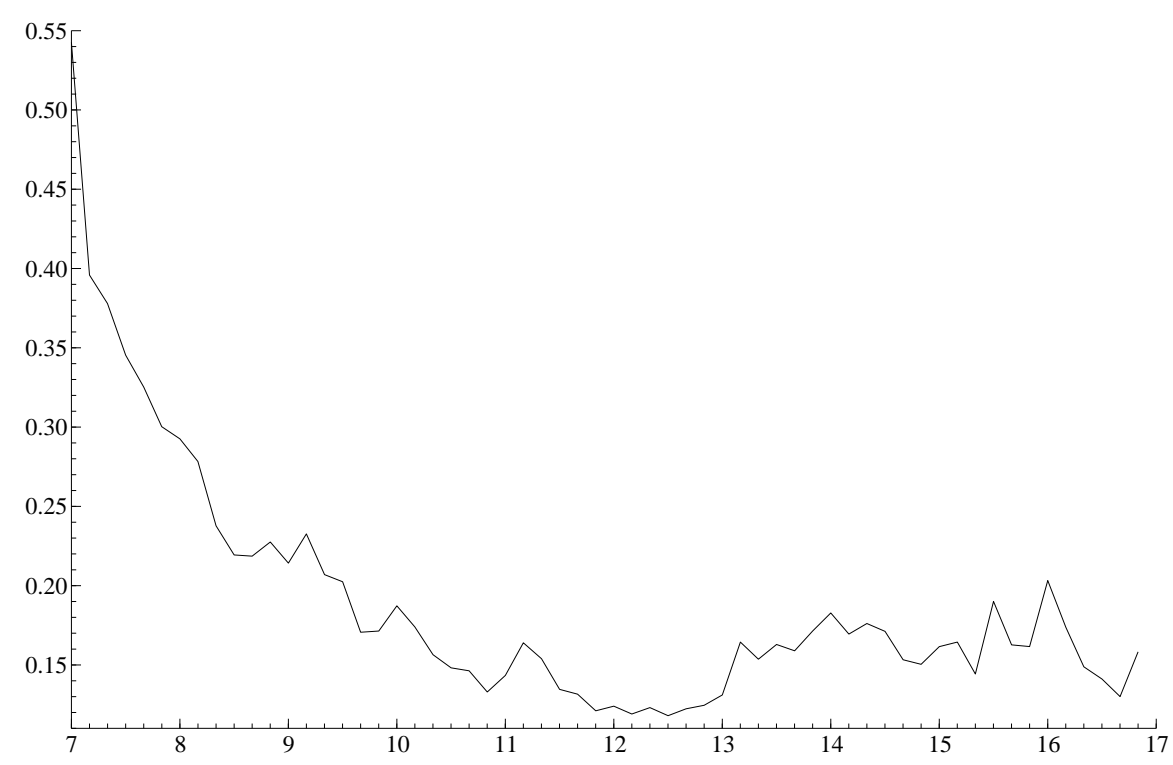

Figure 3: Average absolute 10-minutes EUA returns for each 10-minute interval during a trading day.

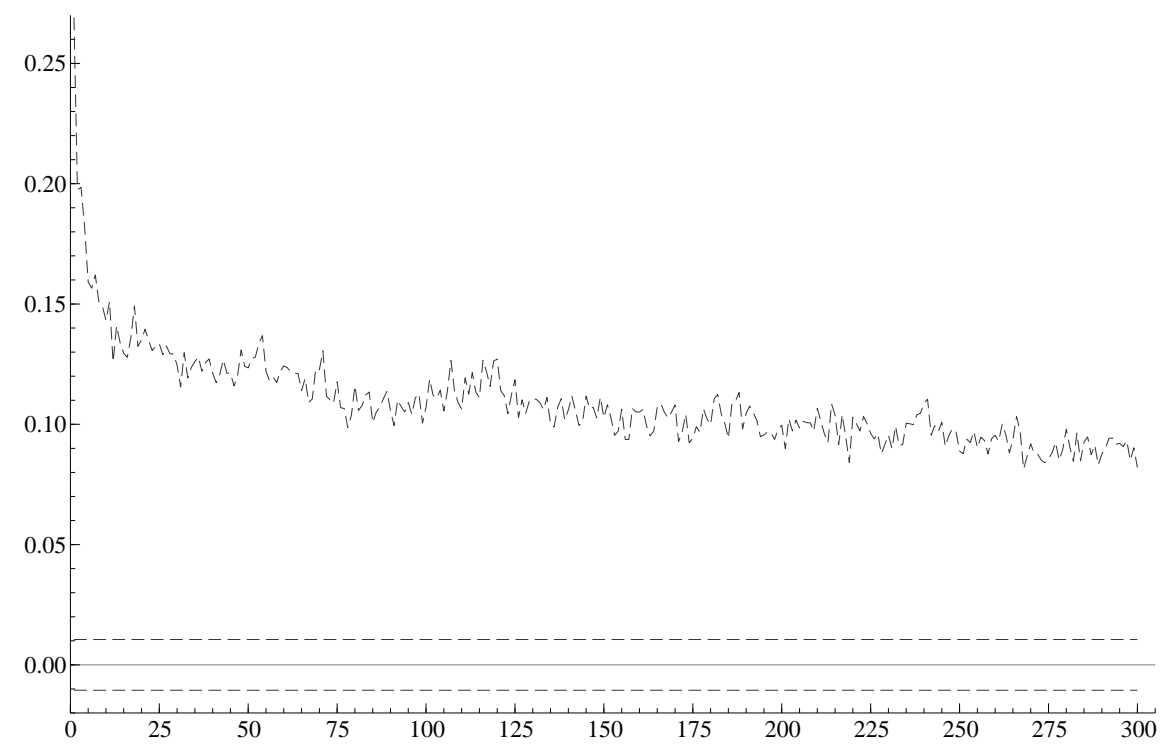

Figure 4: Autocorrelation function of filtered 10-minutes absolute EUA returns for five consecutive trading days. Dashed lines are $95 \%$ confidence bands. 
Table 1: Announcement Data and Tests of Unbiasedness of Expectations

\begin{tabular}{|c|c|c|c|c|c|}
\hline Announcement & \# obs. & $\beta_{1}$ & $\beta_{2}$ & $R^{2}$ & Wald test \\
\hline \multicolumn{6}{|l|}{ Policy Variable } \\
\hline EU NAP & 27 & $\begin{array}{l}0.434 \\
(1.397)\end{array}$ & $\begin{array}{l}0.982 \\
(0.011)\end{array}$ & 0.997 & $\begin{array}{l}1.75 \\
{[0.194]}\end{array}$ \\
\hline \multicolumn{6}{|l|}{ Future Economic Outlook } \\
\hline DE Ifo index & 28 & $\begin{array}{l}-4.072 \\
(3.736)\end{array}$ & $\begin{array}{l}1.038 \\
(0.037)\end{array}$ & 0.968 & $\begin{array}{c}0.93 \\
{[0.408]}\end{array}$ \\
\hline DE ZEW index & 29 & $\begin{array}{l}-1.068 \\
(2.192)\end{array}$ & $\begin{array}{l}0.925 \\
(0.061)\end{array}$ & 0.893 & $\begin{array}{c}0.88 \\
{[0.428]}\end{array}$ \\
\hline EU consumer confidence & 28 & $\begin{array}{l}0.069 \\
(0.469)\end{array}$ & $\begin{array}{l}1.051 \\
(0.032)\end{array}$ & 0.977 & $\begin{array}{c}3.15 \\
{[0.059]}\end{array}$ \\
\hline US Uni-Michigan index adv. & 29 & $\begin{array}{l}2.724 \\
(4.389)\end{array}$ & $\begin{array}{l}0.956 \\
(0.058)\end{array}$ & 0.910 & {$\left[\begin{array}{c}0.51 \\
{[0.604]}\end{array}\right]$} \\
\hline DE new orders & 29 & $\begin{array}{l}-0.008 \\
(0.006)\end{array}$ & $\begin{array}{l}1.821 \\
(0.006)\end{array}$ & 0.334 & $\begin{array}{c}2.83 \\
{[0.076]}\end{array}$ \\
\hline EU new orders & 28 & $\begin{array}{l}0.004 \\
(0.003)\end{array}$ & $\begin{array}{l}1.206 \\
(0.146)\end{array}$ & 0.724 & $\begin{array}{c}1.35 \\
{[0.277]}\end{array}$ \\
\hline US nonfarm payrolls & 27 & $\begin{array}{l}-16.220 \\
(11.029)\end{array}$ & $\begin{array}{l}1.067 \\
(0.051)\end{array}$ & 0.941 & $\begin{array}{c}2.29 \\
{[0.121]}\end{array}$ \\
\hline \multicolumn{6}{|l|}{ Current Economic Activity } \\
\hline$\overline{\mathrm{DE} \text { industrial production }}$ & 29 & $\begin{array}{l}-0.003 \\
(0.003)\end{array}$ & $\begin{array}{l}1.586 \\
(0.243)\end{array}$ & 0.611 & $\begin{array}{c}3.99 \\
{[0.030]}\end{array}$ \\
\hline EU industrial production & 28 & $\begin{array}{l}0.000 \\
(0.001)\end{array}$ & $\begin{array}{l}0.950 \\
(0.100)\end{array}$ & 0.776 & $\begin{array}{c}0.13 \\
{[0.876]}\end{array}$ \\
\hline FR industrial production & 29 & $\begin{array}{l}-0.003 \\
(0.002)\end{array}$ & $\begin{array}{l}1.446 \\
(0.326)\end{array}$ & 0.421 & $\begin{array}{c}2.17 \\
{[0.133]}\end{array}$ \\
\hline GB industrial production & 29 & $\begin{array}{l}-0.003 \\
(0.001)\end{array}$ & $\begin{array}{l}1.742 \\
(0.199)\end{array}$ & 0.740 & $\begin{array}{l}14.97 \\
{[0.000]}\end{array}$ \\
\hline US ISM manufacturer index & 29 & $\begin{array}{c}1.808 \\
(3.276)\end{array}$ & $\begin{array}{l}0.960 \\
(0.067)\end{array}$ & 0.883 & $\begin{array}{c}0.23 \\
{[0.796]}\end{array}$ \\
\hline \multicolumn{6}{|c|}{$\begin{array}{l}\text { Notes: The first two columns contain the name and the number of observations of the announcement } \\
\text { series. The third to fifth columns contain the estimates from the regression } y_{t, k}^{i}=\beta_{1}+\beta_{2} \cdot \widehat{y}_{t, k}^{i}+\eta_{t, k}^{i} \\
\text { and the corresponding } R^{2} \text {. The last column shows the results of a Wald test of the joint hypothesis } \\
H_{0}: \beta_{1}=0 \text { and } \beta_{2}=1 \text {. Numbers in parentheses are standard errors, numbers in brackets are } \\
p \text {-values. }\end{array}$} \\
\hline
\end{tabular}


Table 2: GARCH Models at 10-Minutes Frequency

\begin{tabular}{|c|c|c|c|c|}
\hline & AGARCH & APGARCH & FIAGARCH & FIAPGARCH \\
\hline \multicolumn{5}{|c|}{ Mean Equation } \\
\hline$\mu$ & $\begin{array}{l}-0.0116 \\
(0.0074)\end{array}$ & $\begin{array}{c}-0.0111 \\
(0.0073)\end{array}$ & $\begin{array}{l}-0.0102 \\
(0.0070)\end{array}$ & $\begin{array}{c}-0.0097 \\
(0.0069)\end{array}$ \\
\hline$\theta$ & $\begin{array}{c}0.0210^{\star \star \star} \\
(0.0072)\end{array}$ & $\begin{array}{c}0.0212^{\star \star \star} \\
(0.0071)\end{array}$ & $\begin{array}{c}0.0325^{\star \star \star} \\
(0.0070)\end{array}$ & $\begin{array}{c}0.0319^{\star \star \star} \\
(0.0068)\end{array}$ \\
\hline \multicolumn{5}{|c|}{ Variance Equation } \\
\hline$\omega$ & $\begin{array}{c}0.0241^{\star \star} \\
(0.0090)\end{array}$ & $\begin{array}{c}0.0243^{\star \star} \\
(0.0093)\end{array}$ & $\begin{array}{c}0.1274^{\star \star} \\
(0.0286)\end{array}$ & $\begin{array}{c}0.1093^{\star \star} \\
(0.0321)\end{array}$ \\
\hline$\alpha$ & $\begin{array}{c}0.0400^{\star \star \star} \\
(0.0093)\end{array}$ & $\begin{array}{c}0.0386^{\star \star \star} \\
(0.0094)\end{array}$ & & \\
\hline$\phi$ & & & $\begin{array}{c}0.4633^{\star \star \star} \\
(0.0686)\end{array}$ & $\begin{array}{c}0.4491^{\star \star \star} \\
(0.0937)\end{array}$ \\
\hline$\beta$ & $\begin{array}{c}0.9514^{\star \star \star} \\
(0.0118)\end{array}$ & $\begin{array}{c}0.9509^{\star \star \star} \\
(0.0119)\end{array}$ & $\begin{array}{c}0.6200^{\star \star \star} \\
(0.0643)\end{array}$ & $\begin{array}{c}0.5699^{\star \star \star} \\
(0.0936)\end{array}$ \\
\hline$\gamma$ & $\begin{array}{c}0.1144^{\star \star \star} \\
(0.0264)\end{array}$ & $\frac{0.1110^{\star \star \star}}{(0.0250)}$ & $\begin{array}{c}0.1247^{\star \star \star} \\
(0.0270)\end{array}$ & $\begin{array}{c}0.1119^{\star \star \star} \\
(0.0238)\end{array}$ \\
\hline$\delta$ & & $\begin{array}{l}2.0920 \\
(0.1174)\end{array}$ & & $\begin{array}{c}2.1699 \\
(0.0730)\end{array}$ \\
\hline$d$ & & & $\begin{array}{c}0.2812^{\star \star \star} \\
(0.0224)\end{array}$ & $\begin{array}{c}0.2397^{\star \star \star} \\
(0.0296)\end{array}$ \\
\hline $\mathrm{AIC}$ & 3.658 & 3.658 & 3.633 & $3.632^{*}$ \\
\hline $\mathrm{SIC}$ & 3.659 & 3.659 & 3.635 & $3.634^{*}$ \\
\hline$Q^{2}(20)$ & $\begin{array}{l}97.320 \\
{[0.000]}\end{array}$ & $\begin{array}{l}93.245 \\
{[0.000]}\end{array}$ & $\begin{array}{l}23.529 \\
{[0.171]}\end{array}$ & $\begin{array}{l}20.734 \\
{[0.293]}\end{array}$ \\
\hline LR & $\begin{array}{c}933.980 \\
{[0.000]}\end{array}$ & $\begin{array}{c}928.786 \\
{[0.000]}\end{array}$ & $\begin{array}{l}47.206 \\
{[0.000]}\end{array}$ & \\
\hline
\end{tabular}

Notes: The numbers in parentheses are Bollerslev-Wooldridge robust standard errors. ${ }^{\star \star \star},{ }^{\star \star},{ }^{\star}$ indicate significance at the $1 \%, 5 \%$ and $10 \%$ level. $\mathrm{AIC}$ and SIC are the Akaike and Schwartz information criteria. $Q^{2}(20)$ is the Ljung-Box statistic for the squared standardized residuals at lag 20. LR is the likelihood ratio test $L R=2\left[L_{U R}-L_{R}\right]$, where $L_{U R}$ is the likelihood of the unrestricted FIAPGARCH specification and $L_{R}$ the likelihood of the restricted model. The numbers in brackets are $p$-values. 
Table 3: GARCH Models at 30-Minutes Frequency

\begin{tabular}{|c|c|c|c|c|}
\hline & AGARCH & APGARCH & FIAGARCH & FIAPGARCH \\
\hline \multicolumn{5}{|c|}{ Mean Equation } \\
\hline$\mu$ & $\begin{array}{l}-0.0099 \\
(0.0109)\end{array}$ & $\begin{array}{l}-0.0088 \\
(0.0108)\end{array}$ & $\begin{array}{l}-0.0064 \\
(0.0106)\end{array}$ & $\begin{array}{l}-0.0061 \\
(0.0106)\end{array}$ \\
\hline$\theta$ & $\begin{array}{c}0.0080 \\
(0.0110)\end{array}$ & $\begin{array}{c}0.0089 \\
(0.0109)\end{array}$ & $\begin{array}{l}0.0053 \\
(0.0109)\end{array}$ & $\begin{array}{l}0.0058 \\
(0.0107)\end{array}$ \\
\hline \multicolumn{5}{|c|}{ Variance Equation } \\
\hline$\omega$ & $\begin{array}{c}0.0205^{\star \star} \\
(0.0090)\end{array}$ & $\begin{array}{c}0.0208^{\star \star} \\
(0.0090)\end{array}$ & $\begin{array}{c}0.0785^{\star \star} \\
(0.0244)\end{array}$ & $\begin{array}{c}0.0632^{\star \star} \\
(0.0258)\end{array}$ \\
\hline$\alpha$ & $\begin{array}{c}0.0546^{\star \star \star} \\
(0.0137)\end{array}$ & $\begin{array}{c}0.0505^{\star \star \star} \\
(0.0136)\end{array}$ & & \\
\hline$\phi$ & & & $\begin{array}{c}0.3849^{\star \star \star} \\
(0.0829)\end{array}$ & $\begin{array}{c}0.3650^{\star \star \star} \\
(0.1213)\end{array}$ \\
\hline$\beta$ & $\begin{array}{c}0.9361^{\star \star \star} \\
(0.0171)\end{array}$ & $\begin{array}{c}0.9346^{\star \star \star} \\
(0.0170)\end{array}$ & $\begin{array}{c}0.5781^{\star \star \star} \\
(0.0853)\end{array}$ & $\begin{array}{c}0.5134^{\star \star \star} \\
(0.1354)\end{array}$ \\
\hline$\gamma$ & $\begin{array}{c}0.1329^{\star \star \star} \\
(0.0395)\end{array}$ & $\begin{array}{c}0.1256^{\star \star \star} \\
(0.0337)\end{array}$ & $\begin{array}{c}0.1652^{\star \star \star} \\
(0.0365)\end{array}$ & $\begin{array}{c}0.1532^{\star \star \star} \\
(0.0330)\end{array}$ \\
\hline$\delta$ & & $\begin{array}{c}2.2205 \\
(0.1902)\end{array}$ & & $\begin{array}{l}2.1787 \\
(0.1026)\end{array}$ \\
\hline$d$ & & & $\begin{array}{c}0.3118^{\star \star \star} \\
(0.0293)\end{array}$ & $\begin{array}{c}0.2625^{\star \star \star} \\
(0.0420)\end{array}$ \\
\hline $\mathrm{AIC}$ & 3.411 & 3.410 & 3.394 & $3.393^{*}$ \\
\hline $\mathrm{SIC}$ & 3.415 & 3.414 & 3.399 & $3.398^{*}$ \\
\hline$Q^{2}(20)$ & $\begin{array}{l}73.369 \\
{[0.000]}\end{array}$ & $\begin{array}{c}64.137 \\
{[0.000]}\end{array}$ & $\begin{array}{l}22.221 \\
{[0.222]}\end{array}$ & $\begin{array}{l}20.900 \\
{[0.284]}\end{array}$ \\
\hline $\mathrm{LR}$ & $\begin{array}{c}212.754 \\
{[0.000]}\end{array}$ & $\begin{array}{c}206.606 \\
{[0.000]}\end{array}$ & $\begin{array}{l}11.828 \\
{[0.001]}\end{array}$ & \\
\hline
\end{tabular}

Notes: As in Table 2.

Table 4: GARCH Models at 60-Minutes Frequency

\begin{tabular}{|c|c|c|c|c|}
\hline & AGARCH & APGARCH & FIAGARCH & FIAPGARCH \\
\hline \multicolumn{5}{|c|}{ Mean Equation } \\
\hline$\mu$ & $\begin{array}{l}-0.0111 \\
(0.0151)\end{array}$ & $\begin{array}{l}-0.0143 \\
(0.0162)\end{array}$ & $\begin{array}{l}-0.0121 \\
(0.0146)\end{array}$ & $\begin{array}{l}-0.0121 \\
(0.0146)\end{array}$ \\
\hline$\theta$ & $\begin{array}{c}0.0076 \\
(0.0155)\end{array}$ & $\begin{array}{c}0.0083 \\
(0.0165)\end{array}$ & $\begin{array}{c}0.0066 \\
(0.0164)\end{array}$ & $\begin{array}{c}0.0066 \\
(0.0164)\end{array}$ \\
\hline \multicolumn{5}{|c|}{ Variance Equation } \\
\hline$\omega$ & $\begin{array}{c}0.0181^{\star \star \star} \\
(0.0075)\end{array}$ & $\begin{array}{c}0.0171^{\star \star \star} \\
(0.0068)\end{array}$ & $\begin{array}{c}0.0550^{\star \star \star} \\
(0.0252)\end{array}$ & $\begin{array}{c}0.0574^{\star \star \star} \\
(0.0262)\end{array}$ \\
\hline$\alpha$ & $\begin{array}{c}0.0502^{\star \star \star} \\
(0.0126)\end{array}$ & $\begin{array}{c}0.0590^{\star \star \star} \\
(0.0141)\end{array}$ & & \\
\hline$\phi$ & & & $\begin{array}{c}0.5179^{\star \star \star} \\
(0.1182)\end{array}$ & $\begin{array}{c}0.5135^{\star \star \star} \\
(0.1161)\end{array}$ \\
\hline$\beta$ & $\begin{array}{c}0.9407^{\star \star \star \star} \\
(0.0150)\end{array}$ & $\begin{array}{c}0.9413^{\star \star \star} \\
(0.0142)\end{array}$ & $\begin{array}{c}0.6872^{\star \star \star} \\
(0.1018)\end{array}$ & $\begin{array}{c}0.6915^{\star \star \star} \\
(0.1017)\end{array}$ \\
\hline$\gamma$ & $\begin{array}{c}0.1748^{\star \star \star} \\
(0.0517)\end{array}$ & $\begin{array}{c}0.2058^{\star \star \star} \\
(0.0696)\end{array}$ & $\begin{array}{c}0.2150^{\star \star \star} \\
(0.0606)\end{array}$ & $\begin{array}{c}0.2184^{\star \star \star} \\
(0.0674)\end{array}$ \\
\hline$\delta$ & & $\begin{array}{l}1.5505 \\
(0.1918)\end{array}$ & & $\begin{array}{l}1.9673 \\
(0.1739)\end{array}$ \\
\hline$d$ & & & $\begin{array}{c}0.3206^{\star \star \star} \\
(0.0433)\end{array}$ & $\begin{array}{c}0.3303^{\star \star \star} \\
(0.0683)\end{array}$ \\
\hline $\mathrm{AIC}$ & 3.379 & 3.376 & 3.363 & $3.362^{*}$ \\
\hline $\mathrm{SIC}$ & 3.387 & 3.384 & 3.372 & $3.372^{*}$ \\
\hline$Q^{2}(20)$ & $\begin{array}{l}35.484 \\
{[0.000]}\end{array}$ & $\begin{array}{l}42.600 \\
{[0.000]}\end{array}$ & $\begin{array}{l}21.467 \\
{[0.257]}\end{array}$ & $\begin{array}{l}21.560 \\
{[0.252]}\end{array}$ \\
\hline LR & $\begin{array}{l}97.708 \\
{[0.000]} \\
\end{array}$ & $\begin{array}{l}83.170 \\
{[0.000]} \\
\end{array}$ & $\begin{array}{c}0.122 \\
{[0.729]} \\
\end{array}$ & \\
\hline
\end{tabular}

Notes: As in Table 2. 
Table 5: FIAPGARCH Model with Contemporaneous Surprises

\begin{tabular}{|c|c|c|c|}
\hline & 10-min & 30 -min & $60-\min$ \\
\hline \multicolumn{4}{|c|}{ Mean Equation } \\
\hline$\mu$ & $\begin{array}{l}-0.0101 \\
(0.0069)\end{array}$ & $\begin{array}{l}-0.0062 \\
(0.0106)\end{array}$ & $\begin{array}{l}-0.0116 \\
(0.0145)\end{array}$ \\
\hline$\theta$ & $\frac{0.0328^{\star \star \star}}{(0.0069)}$ & $\begin{array}{l}0.0048 \\
(0.0107)\end{array}$ & $\begin{array}{l}0.0052 \\
(0.0164)\end{array}$ \\
\hline EU NAP & $\begin{array}{l}-3.0934^{\star \star} \\
(1.2296)\end{array}$ & $\begin{array}{c}-0.7709^{+} \\
(0.5260)\end{array}$ & $\begin{array}{c}-0.6214^{\star \star} \\
(0.2932)\end{array}$ \\
\hline DE Ifo index & $\begin{array}{l}0.0278 \\
(0.1419)\end{array}$ & $\begin{array}{l}-0.1315 \\
(0.1971)\end{array}$ & $\begin{array}{l}-0.1357 \\
(0.2083)\end{array}$ \\
\hline DE ZEW index & $\begin{array}{l}-0.1049 \\
(0.1693)\end{array}$ & $\begin{array}{l}-0.1218 \\
(0.2364)\end{array}$ & $\begin{array}{l}0.2527 \\
(0.1856)\end{array}$ \\
\hline EU Consumer confidence & $\begin{array}{l}0.0891 \\
(0.2944)\end{array}$ & $\begin{array}{l}-0.1965 \\
(0.2732)\end{array}$ & $\begin{array}{l}-0.2676 \\
(0.1937)\end{array}$ \\
\hline US Uni-Michigan index adv. & $\begin{array}{l}0.0785 \\
(0.1451)\end{array}$ & $\begin{array}{l}0.1313 \\
(0.1894)\end{array}$ & $\begin{array}{l}0.1862 \\
(0.1710)\end{array}$ \\
\hline DE new orders & $\begin{array}{l}0.2348 \\
(0.2874)\end{array}$ & $\begin{array}{l}0.5003^{\star} \\
(0.2633)\end{array}$ & $\begin{array}{l}0.3147 \\
(0.2334)\end{array}$ \\
\hline EU new orders & $\begin{array}{l}0.0061 \\
(0.2189)\end{array}$ & $\begin{array}{l}-0.2070 \\
(0.1195)\end{array}$ & $\begin{array}{l}-0.1794 \\
(0.1392)\end{array}$ \\
\hline US nonfarm payrolls & $\begin{array}{l}0.3443 \\
(0.3802)\end{array}$ & $\begin{array}{l}0.2618 \\
(0.3200)\end{array}$ & $\begin{array}{c}0.4885^{+} \\
(0.3174)\end{array}$ \\
\hline DE industrial production & $\begin{array}{l}-0.0561 \\
(0.1952)\end{array}$ & $\frac{-0.1201}{(0.2194)}$ & $\begin{array}{c}-0.3112^{\star \star} \\
(0.1535)\end{array}$ \\
\hline EU industrial production & $\begin{array}{l}-0.1101 \\
(0.1204)\end{array}$ & $\begin{array}{l}-0.1891^{+} \\
(0.1262)\end{array}$ & $\begin{array}{c}-0.2969^{\star} \\
(0.1792)\end{array}$ \\
\hline FR industrial production & $\begin{array}{l}-0.0343 \\
(0.2036)\end{array}$ & $\begin{array}{l}-0.1283 \\
(0.2697)\end{array}$ & $\begin{array}{l}-0.0211 \\
(0.2082)\end{array}$ \\
\hline GB industrial production & $\begin{array}{l}0.1336 \\
(0.3101)\end{array}$ & $\begin{array}{l}0.2034 \\
(0.1812)\end{array}$ & $\begin{array}{l}0.1487 \\
(0.1574)\end{array}$ \\
\hline US ISM manufacturer index & $\begin{array}{c}0.1001 \\
(0.2704) \\
\end{array}$ & $\begin{array}{c}-0.4439^{\star \star} \\
(0.1932)\end{array}$ & $\begin{array}{c}-0.3859 \\
(0.2818) \\
\end{array}$ \\
\hline \multicolumn{4}{|c|}{ Variance Equation } \\
\hline$\omega$ & $\begin{array}{c}0.1125^{\star \star \star} \\
(0.0338)\end{array}$ & $\begin{array}{c}0.0632^{\star \star} \\
(0.0260)\end{array}$ & $\begin{array}{c}0.0550^{\star \star} \\
(0.0255)\end{array}$ \\
\hline$\phi$ & $\begin{array}{c}0.4304^{\star \star \star} \\
(0.0979)\end{array}$ & $\begin{array}{c}0.3631^{\star \star \star} \\
(0.1242)\end{array}$ & $\begin{array}{l}0.5258^{\star \star \star} \\
(0.1122)\end{array}$ \\
\hline$\beta$ & $\begin{array}{c}0.5507^{\star \star \star} \\
(0.1006)\end{array}$ & $\begin{array}{c}0.5093^{\star \star \star} \\
(0.1386)\end{array}$ & $\begin{array}{c}0.7066^{\star \star \star} \\
(0.0954)\end{array}$ \\
\hline$\gamma$ & $\begin{array}{c}0.1178^{\star \star \star} \\
(0.0235)\end{array}$ & $\begin{array}{c}0.1534^{\star \star \star} \\
(0.0331)\end{array}$ & $\begin{array}{c}0.2211^{\star \star \star \star} \\
(0.0680)\end{array}$ \\
\hline$\delta$ & $\begin{array}{l}2.1814 \\
(0.0742)\end{array}$ & $\begin{array}{l}2.1818 \\
(0.1029)\end{array}$ & $\begin{array}{l}1.9519 \\
(0.1793)\end{array}$ \\
\hline$d$ & $\begin{array}{c}0.2344^{\star \star \star} \\
(0.0299)\end{array}$ & $\begin{array}{c}0.2609^{\star \star \star} \\
(0.0420)\end{array}$ & $\begin{array}{c}0.3387^{\star \star \star \star} \\
(0.0702)\end{array}$ \\
\hline$Q^{2}(20)$ & $\begin{array}{l}20.914 \\
{[0.284]} \\
\end{array}$ & $\begin{array}{l}19.928 \\
{[0.337]} \\
\end{array}$ & $\begin{array}{l}21.099 \\
{[0.274]} \\
\end{array}$ \\
\hline $\begin{array}{l}\text { Notes: The numbers in pare } \\
\text { dard errors. }{ }^{\star \star \star},{ }^{\star \star},{ }^{\star},+ \text { indi } \\
\text { level. The numbers in bracke }\end{array}$ & $\begin{array}{l}\text { Bollerslev- } \\
\text { ince at the } \\
\text { es. }\end{array}$ & $\begin{array}{l}\text { ooldridge ro } \\
\%, 5 \%, 10\end{array}$ & $\begin{array}{l}\text { ust stan- } \\
\text { and } 15 \%\end{array}$ \\
\hline
\end{tabular}


Table 6: FIAPGARCH Model with Lagged Surprises at 10-Minutes Frequency

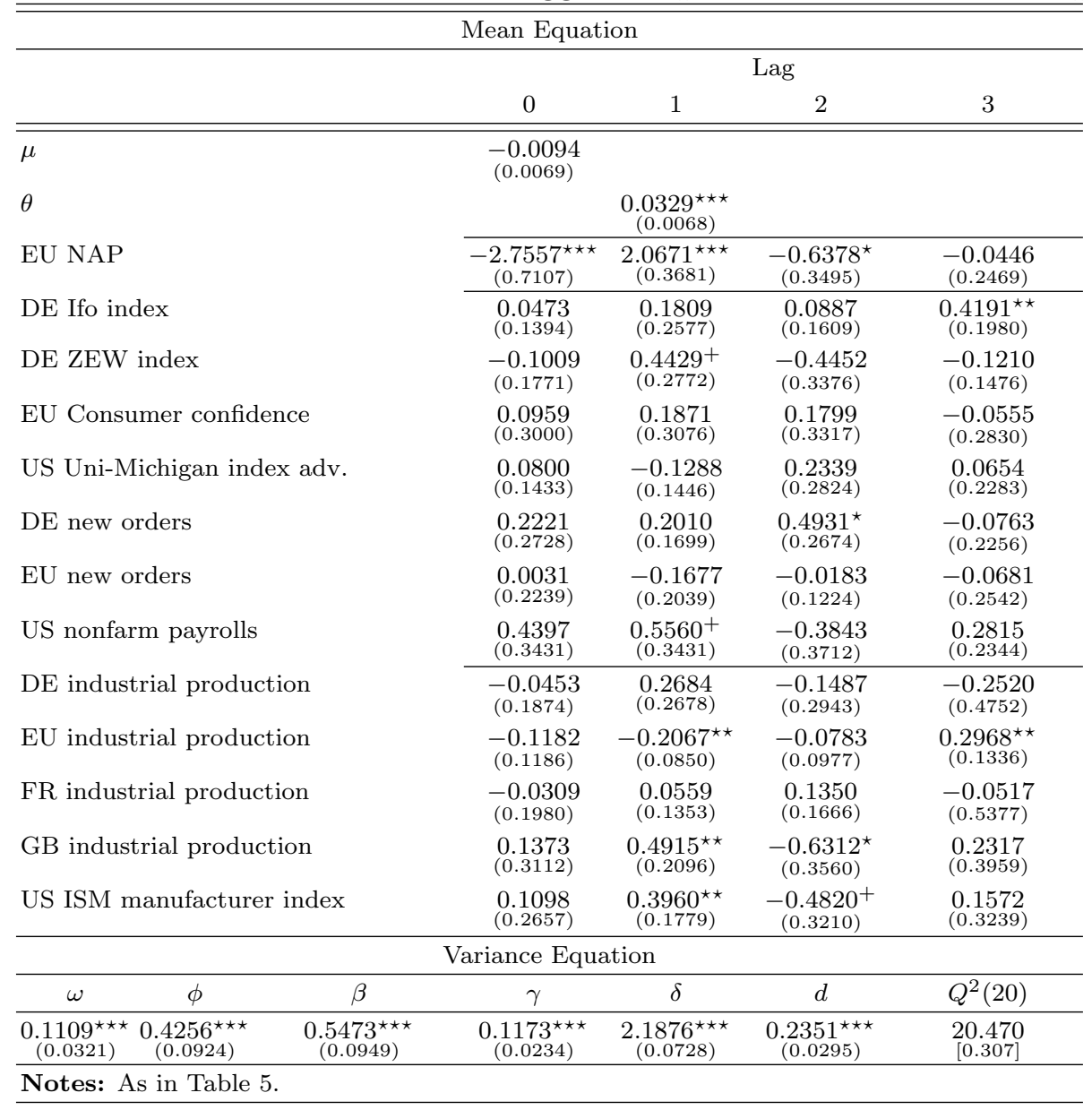

